\title{
NON-AMERICAN BLACK WOMEN'S EMPOWERMENT: A FOURTH-WAVE FEMINISM STUDY ON CHIMAMANDA NGOZI ADICHIE'S AMERICANAH
}

\author{
Maria Ardianti Kurnia Sari, Nur Saktiningrum \\ Faculty of Cultural Sciences, Universitas Gadjah Mada \\ Email: mariaardianti@mail.ugm.ac.id, saktiningrum@ugm.ac.id
}

\begin{abstract}
Racial issues have been a big problem in the United States of America since the slavery era. Although racism still exists in its society, many people are still migrating to America. For example, non-American Black women go there to try their luck to get a better education, a better job, and a better standard of living. However, some of them experience racism and gender inequality at work, as well as everywhere else in American society. Nevertheless, these experiences of racism and inequality may well be what motivates them to gain empowerment and gender equality. The qualitative method is used in this research. The primary source is a novel by Chimamanda Ngozi Adichie titled Americanah (2013). The secondary sources to support this analysis are books, journals, articles, videos, and current news related to the issues. Post-nationalist studies by John Rowe, transnationalism studies by Steven Vertovec, fourth-wave feminism ideas from Nikola Rivers and Prudence Chamberlain, and Black women's empowerment studies by Sheila Radford-Hill and Patricia Hill Collins are used to analyze the data. The results of this research are: first, there are measures taken by non-American Black women to gain empowerment in the US, which begin with their aspirations to obtain acceptance in society. Second, the redefinition of gender equality through education, employment, and social changes leads to the acceptance of non-American Black women in society. The acceptance and empowerment become evidence of gender equality in education, employment, and social life.
\end{abstract}

Keywords: racism, non-American Black, women, empowerment, gender equality

\begin{abstract}
ABSTRAK
Isu rasisme menjadi salah satu masalah besar di Amerika Serikat sejak masa perbudakan. Meskipun rasisme masih terjadi, tetapi tidak sedikit imigran yang datang dan menetap. Wanita kulit hitam dari luar Amerika datang untuk mendapat pendidikan, pekerjaan, dan hidup layak. Tetapi, tidak sedikit mendapatkan rasisme dan ketidaksetaraan gender di dalam dan masyarakat. Dengan demikian, rasisme dan ketidaksetaraan memotivasi wanita kulit hitam non-Amerika untuk memperoleh pemberdayaan dan kesetaraan gender. Metode kualitatif digunakan dalam penelitian ini. Sumber pertama, novel karya Chimamanda Ngozi Adichie berjudul Americanah (2013). Sumber kedua untuk mendukung analisis diambil dari beberapa buku, jurnal, artikel, video, dan berita yang berhubungan dengan isu yang dibahas. Beberapa teori yang digunakan untuk menganalisis, yakni teori pos-nasionalis dari John Rowe, transnasionalisme dari Steven Vertovec, feminisme gelombang keempat dari Nikola Rivers dan Prudence Chamberlain, dan pemberdayaan perempuan berkulit hitam dari Sheila Radford-Hill dan Patricia Hill Collins. Berdasarkan hasil analisa, pertama, pemberdayaan wanita kulit hitam non-Amerika dimulai dari perjuangan mereka untuk mendapatkan pemberdayaan dari masyarakat. Proses perjuangan dan keberanian yang menuntun mereka untuk bisa beradaptasi dengan situasi di Amerika. Kedua, mendefinisikan kesetaraan gender dalam dunia pendidikan, pekerjaan, dan perubahan sosial. Beberapa dampak pemberdayaan menjadi bukti pencapaian kesetaraan gender dalam dunia pendidikan, pekerjaan, dan perubahan kehidupan sosial.
\end{abstract}

Keywords: rasisme, orang kulit hitam non-Amerika, wanita, pemberdayaan, kesetaraan gender 


\section{INTRODUCTION}

Racial problems are a sensitive matter to discuss in the United States of America. The country had a myriad of racial problems during its conception, and it still does today. While there are many people of color in the United States, especially African-Americans, who still receive racist treatments, the trend only rose since Donald Trump became president of the United States. Wootson Jr. et al. (2020) argue that 65 percent of African-Americans say that they are not comfortable living among whites in the US However, about 77 percent of Black Americans enjoy living in the United States even though they have to act white. Therefore, it is safe to say that after centuries of slavery and mass migrations, racial problems have persisted well into the $21^{\text {st }}$ century US. On the other hand, we have "colorblindness" or the act of removing bias on other races. In this case, we are talking about removing prejudice against the people of color, especially Black people, in the US. In the current politics, white Americans are expected to be accepting of the Black cultures present among Black Americans or non-American Black people in the US, along with the notion that they are expected to be open to different or new cultures formed by different age groups, races and ethnic groups, gender identities, and social minorities.

Just as important as racial issues is the issue of gender equality. This has become a central topic throughout the fourth wave of feminism. The feminist movement aims to call for justice, equal pay, equal work, and physical autonomy, and it uses both print and online media such as Facebook, Twitter, blogs, and other social media platforms to speak out against all sorts of abuse of power. However, empowering women in the $21^{\text {st }}$ century, in terms of getting their surroundings to help them overcome various challenges, has not been easy. Many are still of the notion that women cannot become successful or have higher roles than men. United Nation Women (2020: 5) claims "women between the ages of 20 and 24 in the lowest income category appear to be more likely to give birth before the age of 18". This shows that if women do not have good enough education, they tend to get married at a young age without ever having the chance to learn and show their true potentials. The lack of awareness of how critical it is for women and girls to gain education is a major concern. Belalcázar et al. (2015: 32) believes that "women empowerment should be done through education". There are some life options that can improve their welfare, such as getting married at an appropriate age and having fewer children. Education empowers women, and it will increase their understanding of their rights in society as well as their confidence to defend those rights.

The issue of education brings the attention of this research to Nigerian author Chimamanda Ngozi Adichie and her novel Americanah (2013). As a feminist, she shows her concerns about education and women's rights by writing a number of books. Born in 1977, Adichie moved to the United States at the age of 19 to get a better education, but was met with racial discriminations because of her black skin and Afro hair. Similarly, Americanah talks about the struggle of a Nigerian woman named Ifemelu. This character moves to the United States to pursue education because the lecturers at her Nigerian university are on strike. Now a non-American Black woman studying in a US university, she initially struggles to know her way around and sometimes faces prejudice from her surroundings (for example, even her white boyfriend thinks it is a good idea that she straightened her hair to get a better job). Ifemelu then goes on to write a famous blog about her experiences as a non-American Black woman in the US. The blog is called Raceteenth or Various Observations about American Blacks (Those Formerly Known as Negroes) by a Non-American Black.

The first focus of this research is to explore the empowerment of women through the perspectives of non-American Black women, specifically through the novel Americanah as its primary material. The researcher looks at how the fourth-wave of feminism has affected this novel. As its second focus, this research analyzes the impacts of women empowerment from a transnational perspective, using the main character's migration from Nigeria to the United States - and then returns to Nigeria - as a discussion point.

For this study, the researcher used a qualitative approach. To help dissect the primary text, various books, articles, journals, videos, and current news were reviewed to find relevant ideas that support the arguments. John Rowe's post-nationalist studies, Steven Vertovec's transnationalism studies, fourthwave feminism ideas from Nikola Rivers and Prudence Chamberlain, as well as Black women's empowerment studies by Sheila Radford-Hill and Patricia Hill Collins were used to analyze the data. 
Stories, either fiction or real-life, of the empowerment of non-American Black women in the US are often powerful. It is usually racism and inequality that become a drive for the characters to gain recognition. With the courage to persist through difficult experiences, they are continually empowered to reach a better life, although at the cost of having to adapt to the American culture and adopt certain behaviors. Moreover, by redefining equality through education, employment, and social changes, nonAmerican Black women make their impacts in society. The ups and downs of living in a foreign land only prove to non-American Black women that challenges are not insurmountable.

\section{FINDINGS AND DISCUSSION}

Stories of women empowerment tell of women who show their strength and prove their worth as their search for opportunities. They also tell of how women strive to attain gender equality in society or in their communities despite their less than advantageous backgrounds. However, it is important to put these stories in context. This research aims to explore the influence of fourth-wave feminism on the novel Americanah. This feminist movement focuses on how women can be empowered by adopting the concept of "intersectionality". This concept is defined as a movement that encourages women to become aware of marginalized politics, economics, and social events that occur due to gender, sexual preference, race, and class (Asmarani, 2015). Moreover, "empowerment" actually has a special significance in society, in that empowering women eventually aims to nurture relationships that are filled with love, respect, friendship, and legitimacy (Rahman, 2013).

However, Radford-Hill (2000) argues that due to institutional discrimination, there are still a lot of challenges facing gender relations in the $21^{\text {st }}$ century. Specifically in Americanah, the injustice is seen in how Black women face a new world dominated by white people. One example of institutional discrimination has women placed in a subordinate position due to practices and policies that apply gender roles. It is weird for women to become leaders if the practices and policies in society or communities dictate it so. Thus, according to Kabeer (2005), gender-related inequalities can lead to poverty. In cases where women are the breadwinners for their families, discrimination and gender problems often arise at the workplace. In societies that apply gender roles in a strict manner, women are either discriminated against at the workplace or banned from working altogether. Now add racial discrimination into the mix, and you have a recipe for powerful stories of struggle for recognition and success, both in real and in fictions.

In Americanah, after thirteen years living in America, Ifemelu presents the reader with a view on a specific aspect of her life as she goes to an African hair braiding salon to redo her braids. In this description she gives a glimpse of how non-American Black women can get empowerment from society. It means that as far as they can prove their worth and dedication, non-American Black women can surmount the difficulties of living in the US

She gave the taxi driver the address of Mariama African Hair Braiding. It was her first time at this salon - her regular one was closed because the owner had gone back to Cote d'Ivoire to get married - but it would look, she was sure, like all the other African hair braiding salons she had known. (Adichie, 2013: 10)

The quote above gives an insight of how non-American Black women can have the privilege of starting their own business. In the book, the owner of the salon, Mariama, says that she and her sister Halima come from Mali, and her assistant Aisha is from Senegal. Hair is an important thing to Black people, American and non-American alike. It holds both cultural and spiritual importance, thus in a way it also stands as a symbol of women empowerment, which is aptly used by Adichie in her novel in the context of economy. Black women with an afro like to be creative with their hair. A few of them see the opportunity of opening salons in the US because some, including career women, do not have time to braid their own hair. This way, Americanah presents a clever way of presenting hair that already holds such importance to women as a reminder of a cultural and spiritual legacy that gives them the opportunity to be economically empowered. In a way, this provides an answer to the question that feminists would ask about what "empowerment" as a concept actually mean. To Black people, empowerment can stem from recognizing the things that are already inherent in themselves - physically, culturally, and spiritually.

Moreover, empowerment is also shown in 
the character Aunty Uju. The novel presents her as a Black woman who strives to obtain her license to become a doctor in the US. In one scene, Ifemelu finds an envelope that reads the United States Medical Licensing Examination. Comically, they make sure that it is not a thick envelope, because a thick envelope would mean that she has failed yet again and has to take another test (Adichie, 2013: 146). This part hints that the way to empowerment is by reaping the results of efforts that one has made. Kabeer (2005) points out that accomplishments refer to the degree to which the potential has been realized. In other words, it all boils down to the efforts made by the individuals. "The relationship between empowerment and achievements is considered both in terms of performance and its consequences" (Kabeer, 2013: 15).

Achievements and empowerment become parameters for immigrants' efforts to fit in peacefully and have a better standard of living despite racial and gender discriminations. It is important to understand that the words "achievement" and "empowerment" are powerful incentives for immigrants, particularly non-American Black women. Rowe (2000: 24) explains that in the US, non-American Blacks are often discriminated against, and this makes it challenging for them to live in the country. In relation to this, there are social disparities in educational and economic opportunities. "Class hierarchies have therefore become a main concern. Class becomes a category that is often bound up in social practice with historically established hierarchies of race, ethnicity, gender, sexuality, and religion".

Women all over the world are dealing with similar concerns. Many countries around the world do not have an established policy on gender equality. Meanwhile, it should already be recognized that discriminating against women based on their gender, namely propagating the notion that men and women cannot acquire the same accomplishments, is not acceptable. Belalcázar et al. (2015: 30) notes that '"empowerment' is part of a continuum of human growth". Thus, empowerment can hugely impact non-American Black women in their efforts to be motivated and be part of a modern US.

All the non-American Black women mentioned in Americanah display great courage to survive in the face of discrimination and inequality. Empowerment has made major impacts that help them get through difficult experiences. Initially, life in America turns out to be not as easy as they expected. However, their enthusiasm and passion become the drives that keeps them going as they navigate their way through the process of adapting, embracing, and enjoying what the new place has to offer. As immigrants, they have to be prepared for the risks and consequences that living in a new society can bring. On the other hand, living on one's own in another country can bring a certain form of independence.

Saujani (2016), in her TED Talk mentions that everyone has ambition. She continues by saying that all women should have the confidence to speak up in the face of injustice. Without courage, there will be no empowerment for women, and they will live in inequality for the rest of their lives. Based on fourthwave feminism studies, there are three indicators of such empowerment as the novel also suggests: equality in education, employment opportunities, and social changes.

\section{Gender Equality in Education}

The existence of Black people in the US is inseparable from the forced migrations that befell their ancestors in the era of slavery. Since then, Black women, American or non-American, have sought to rise above the slave status and fight the discriminations perpetrated against them. It became clear to them early on that the way to do so was through education.

Notwithstanding age, gender, and race, education is an important issue for many. Especially for women, education is a vital platform for empowerment. Moreover, as education is the way to achieve other important development goals, only through education can women achieve those goals, be motivated, and even consider obtaining equal privileges as the already educated group. Hunt (2013) points out that education is important for women because, through better education, women will gain greater access to economic or job opportunities. Nowadays, more and more professions require educational background, and not race, as their main consideration.

Accordingly, education is the first aspect to be explored in Americanah. The main character, Ifemelu, decides to move to America to continue her education amid the ongoing strike that involves the lecturers at her previous university (Adichie, 2013). Reasonably, 
the empowerment that she receives begins with her family, and it becomes the greatest influence for her to make the decision to move as an effort to achieve her future goals. As the empowerment of women can increase their development (Duflo, 2012), the support she gets from her family becomes an important part of her personal development.

Education becomes a medium to empower someone to be a better person. Through education, people will see how women, especially the immigrants or diaspora, can improve themselves as empowered human beings in other countries. One of the proofs to be empowered is having the bravery to adapt to the new society; for instance, in the classroom, they are trying to give their opinion freely without thinking about what gender they have. (Adichie, 2013: 167-169).

Empowering Black immigrant women is crucial in their effort to fit in. It is not easy for everyone to adapt to a new place; they will need time to find their way around and adapt to a new culture. The US can be a difficult place for migrant workers, to some of whom The American Dream may as well remain a dream. The achievement of international education is an honor for some international students, particularly Black immigrant women. They have to compete with each other and everyone else to get the best in education and only the successful ones will continue to have celebrated positions. For some, the foreign environment provides opportunities for them to show their talents and abilities. As a result, these opportunities will improve their ability to interact globally with various experts.

In the novel, Ifemelu acquires a positive reputation for her future; going abroad and forming relationships with professionals grant her the opportunity to gain valuable experiences. As long as Black immigrant women are open to growth and interaction with those who are more experienced, the effects may be beneficial. These positive impacts make them feel empowered by their environments and families, as other people understand their presence. The experiences that they collect along the way should in turn inspire others struggling to achieve their own empowerment. In addition, being international students in America, Black immigrant women are encouraged to have the confidence to express their critical thinking and ideas. The exchange of information with others - that sharing of knowledge and opinions - will enhance other people's perceptions into the uniqueness of other cultures. (Collins, 2000) argues that empowering women starts with ideas and acts that can influence the power of development. Reading a book will provide a little example of how power is created. This development will lead women to empowerment because by learning a simple thing, they will experience the information that is provided by reading, especially the freedom to choose what women want.

Tijani (2016) mentions in the article "10,674 Nigerians Studying in the US - Highest in 30 Years" that nearly 11,000 Nigerians attended US schools and universities during the 2015-2016 academic year. Of that number, about 50.8 percent are undergraduate students, 35.6 percent are graduate students, 11.5 percent are in Optional Practical Training programs, and two percent are in non-degree programs or shortterm schools. These statistics indicate that many Nigerians wish to improve their quality of living by moving abroad to the States. Nigerians' passion for education proves that, in 30 years' time, there has been a constant growth in how they perceive education as an important part of their lives.

Casimir (2018) mentions in her article "Data Show Nigerians the Most Educated in the US" that both Black immigrant men and women from Nigeria tend to continue their studies in the US to get higher degrees. For example, those who have earned their bachelor's degree are likely to continue to study for a Master's degree. The statistics show how Nigeria is leading the pack of African countries sending their best and brightest to the US to pursue formal education. This can be linked to the notion that it is part of their conscience to continue to rise above the collective memory of slavery. This is in line with (Vertovec, 2009) who mentions in his book entitled "Transnationalism" that transnationalism presents a topic of rapidly growing academic interest because transnationalism itself becomes the interest of students in all around the world to continue their study abroad to get a better education.

\section{Better Employment Opportunities}

Better employment opportunities may mean having enough to cover one's basic necessities and everyday 
needs. For many, there is also that responsibility of providing for their family. It is certainly ideal that one can get a decent job and earn a good pay without being discriminated against in terms of ethnicity, gender, race, sexuality, and social class. However, that is often not the case, and things are especially harder for Black women, American or non-American, in the US

About 80 percent of Black mothers are breadwinners for their families, placing them at labor participation. Black women or mothers dominate the workforce, and yet they do not change the practices of their employers. This means that Black women continue to be discriminated against, resulting in lower wages and less secure jobs relative to white women. In America, the institutional domain of influence, which includes social institutions, is designed to reproduce the subordination of Black women over time (Collins, 2000). Subordination, which is formed by social structures, makes it difficult for non-American Black women as it is gender-based. Subordination, which is divided by race, class, and gender, still exists in American society.

In Americanah, landing a job is not as easy for Ifemelu as she expected. Neither does the duration of life abroad guarantee that it is easy to find formal employment. For example, in her five years of living abroad, Aunty Uju must receive professional training and obtain a professional license in order to land a professional job and become a doctor (Adichie, 2013). The ups and downs of living abroad as immigrants represent the challenges in achieving empowerment. The effects of empowerment can be felt when sacrifices are rewarded by gender equality, formal jobs, and equal pay.

On the other hand, international students such as Ifemelu find it hard to get a proper job. American companies do not readily accept students as listed employees since working with only student visas in hand can bring about all sorts of problems with the immigration office. Aunty Uju then suggests that Ifemelu borrow the ID of one of her relatives in the US This, however, is problematic because then she will have to pretend to be someone else (Adichie, 2013).

The novel portrays how finding a job in the new land proves to be a struggle for Ifemelu. She cannot simply use her student visa, and she does not have the extra paperwork required to get a formal job. Aunty Uju's suggestion that she borrows someone else's ID card may be the best option for her to raise the money she needs to pay for her tuition fee, something her aunt cannot help her with. Not only is it challenging for her to pretend to be someone else, it is also illegal to use someone else's ID card to work.

Furthermore, becoming part of a diaspora in another country is not always easy, especially if one is studying abroad while having to do a part-time job. According to (Vertovec, 2009) "diaspora belongs to migration, minority, and transnationalism, as they belong to communities that lived in foreign parts of the world" (p. 130). Aunty Uju and Ifemelu, for example, as Black immigrant women, must face the challenges of living life in America.

Somewhere in the novel, Ifemelu gets a part-time job as a babysitter through the support of a character named Ginika. This is Ifemelu's first experience as a babysitter. Kimberly and her husband, the white couple that employ her, look past Ifemelu's status as a non-American Black woman. They learn a lot about Ifemelu's background, which provides them with a better perspective toward Nigerian culture. Ifemelu works for the couple for months, and she later learns how the opportunity that was given to her has changed her life.

Statistics from the Labor Force Participation, Employment, and Unemployment Rates, by Race and Sex, 2000 as mentioned in Spalter-Roth and Lowenthal (2005) shows that the employment of white people in the US makes up around 61.1 percent of the employed. Meanwhile, the working Black and AfricanAmericans, male and female, reached 52.5 percent of the Black population. Also from the statistics, 52.8 Black and African-American women dominate the number of Black people in America who work. Later, based on the "Labor Force Characteristics by Race and Ethnicity, 2009" (2010: 7), at the beginning of Obama's presidency in 2009, " 56.1 percent of Black women were working". The comparison of statistics reminds us of how many Black women had needed those jobs before Obama was elected president, and how the actual opportunities only arrived after that huge empowering momentum of Obama taking office as president.

\section{Improvements in Living Standards}

Actual improvements in living standards remind us that equality can exist in society. For some, it starts with the struggle to live abroad and to gain approval 
or recognition from others. Such changes are depicted in the novel, which tells of Ifemelu's move to the US and other women who moved there before here, as well as their efforts to build a better future.

Aunty Uju, Ifemelu's aunt, loves her job as a non-American Black doctor in America. She knows how hard it is to be a Black woman and a single mother in America. Her struggle to become a doctor, however, pays off. Living with her son, she tries to leave her past life behind to live happily in the country where her dream has been built (Adichie, 2013, pp. 270-271).

However, Ifemelu notes that "Even in America, Race Is Class" (Adichie, 2013: 205). That is the title of one of Ifemelu's blog entries. In the US, when she works for a white family as a babysitter, she learns that to belong to a race means to belong to a certain class. The subject she talks about in that entry is common. In the US, due to how racism is very much entrenched in the culture, some often do not realize that they are being racist or, ironically, that they are victims of systemic racism.

Sometimes in America, Race Is Class. It didn't matter to him how much money I had. As far as he was concerned, I did not fit as the owner of that stately house because of the way I looked. In America's public discourse, "Blacks" as a whole are often lumped with "Poor Whites." Not Poor Blacks and Poor Whites. But Blacks and Poor Whites. A curious thing indeed. (Adichie, 2013:205)

Rowe (2000: 24) mentions that it is clear that Black immigrant women often get discriminated against because class has become a category that is often bound up in social practice with historically established hierarchies of race, ethnicity, gender, sexuality, and religion. Ifemelu's life changes after she becomes a babysitter at a white family's home. Her part-time job helps her meet her everyday needs, and help her pay for her school fees and the rent for her apartments. Another aspect that changes her life is her encounter with Curt (Adichie, 2013: 241-246). When "color-blindness" is applied in US society, Black immigrant women can have more confidence. As a non-American Black woman with a white boyfriend, Ifemelu feels that she can be herself. She gets the empowerment and inspiration she needs from her boyfriend, his family members, and other white people around her. In fact, "many whites adopt strategic color-blindness, which means they stop talking about race" (Apfelbaum et al., 2008: 918). Color-blindness will motivate and inspire Black people to develop and show their potentials without the issue of race getting in the way.

Additionally, fourth-wave feminism has not merely been defined by academics but is being used by activists and journalists reporting on the ongoing movement. It suggests that the movement has penetrated several disciplinary manifestations of feminism (Chamberlain, 2017a). The acknowledgment of the fourth wave of feminism in journalism or the use of media means that journalism supports the fourth wave's presence. It supports feminist activists sharing and speaking up about their concerns regarding injustice, gender inequality, racism, and others. The use of technology such as the internet has becomes a way for them to get support and encouragement from the other activists.

Fourth-wave feminism and intersectionality also have a significance in that they bring a new concept in the use of technology. Intersectionality in this case occurs as Black feminist critiques the way that it is harder for Black women to gain equality because of their race, class, and gender. In the fourthwave feminism, Black feminists try to use cyberspace to invite other Black women who have experienced racism and sexism or any other related problems to share their stories online, for both data collection and therapy; it is known that sharing ideas and life experiences through writing can become therapy for just about anyone. People around the world with Internet access can read their stories instantly. The interconnectedness created by cyberspace can and have benefited women (Chiang et al. as cited by Shiva \& Kharazmi, 2019). The internet, especially social media, help women exchange ideas with the public and to eventually garner support. Fourthwave feminism especially emphasizes the use of online media for they reach a wider audience, are low costs, and are user friendly, making it a lot easier to encourage other women to speak out against various forms of abuse, discrimination, or other issues directed against women. Much like the third wave before it, fourth-wave feminism is fractured and complex, frequently reinforcing the advancement of the individual and centering the seductive notions of "choice", "empowerment", and "agency". These ideals are present even in feminist activism that seemingly 
undermines or challenges the idea of women - or perhaps more accurately some women - as able to make their own choices outside the constraints of an overtly patriarchal society.

Initially, Ifemelu does not expect that her blog will be read by many people. However, her blog gets more and more hits by the day. Readers worldwide respect her writings, and she gets emails from those who at first only write comments on her posts. One post in particular, titled "What's Love Got to Do with It?", surprises her when it receives so much attention and leads to people from different parts of the world having discussions online. Her sad story of her breaking up with "The Hot Ex" gets the sympathy of other women, and it helps fuel the debates that the ex in question is a white male (Adichie, 2013: 378-379).

As an online activity, blogging opens a wide chance for women to explore their curiosity, especially to explore how the world can give positive inputs for them to continue their activism and share stories that inspire others. The blogosphere is open to anyone, but should especially be used by women to offer frameworks for current social issues. A blog can become a mediated space that women are consciously developing to participate in contemporary feminism (Rivers, 2017).

Going anonymous on her blog in the beginning gives Ifemelu a certain sense of safety. But the success of her blog, especially in the way that her readers get an insight into what is happening in the US and what it is like to be a Black immigrant woman there, encourages her to open up. Her blog gives her a sense of achievement, and leads to an unexpected success story.

Ifemelu's blog is successful in enlightening people who read her posts. She mostly writes about racism, how white people think and do, and what non-American Black should do or act when they are in America. Then, from the blog, she gets an email from princeton.edu address to do her research fellowship and gives a public talk at the end of the year. The pay is good, the requirements are comfortable, and she expects to live in Princeton and uses the library while giving a public talk at the end of the year. (Adichie, 2013: 440)

With her success, she returns to Nigeria. Her concerns about sexism, prejudice, and a particular
non-American Black man has made her realize that America is not her place to live. "She is now becoming an 'Americanah' or a person influenced by or is being Americanized by American cultures" (Adichie, 2013: 476). She is content enough that through her writings, people are getting inspired. It has broadened others' view of racism and discrimination in the US. In her blog, Ifemelu emphasizes that in America, nonAmerican Black people have to understand that they belong to Black people, and the view of distinction becomes more transparent as they, non-American Black people, interact with white people in the crowd. Eventually, it is because of this kind of writing that she gets invited to speak at Princeton and share her experiences with others.

As the internet and rapid advancements in technology have become part of human life, speed is required to exchange information quickly. The Internet's speed has also changed the viewpoint of feminism because everything is now online and global problems are spread rapidly (Chamberlain, 2017b). Rivers (2017) mentions that activism can be done online because feminists all around the world should share their concerns on feminism and be part of a campaign. However, the effects of the online campaign should be offline because the influences need to be felt directly in society. The act must be done toward the people who need help in the real world. As the novel shows, through Ifemelu's viewpoint, others around the world can understand the conditions and particular problems of a group or culture. This allows for, or becomes part of, a bigger discussion on how to solve these particular problems.

\section{CONCLUSION}

Based on the analysis, we can conclude that to many people, the United States of America seems to have it all: the perfect job opportunities, education, and better standards of life in general. As a result, people are coming from all over the world to work or to study, as well as other reasons. They come from a wide variety of ethnic backgrounds: African, Hispanic, European, Asian, etc. Although America is a melting pot, it does not mean that it has been easy for it as a society to get rid of racism. Black people, both African-American and non-American, are among the communities who get seriously discriminated against. Then, if the same Black people were to be categorized by gender, 
Black women would be more easily discriminated against than the men. They would be at a lower level in education, employment, and social life. However, some Black women have also seen their fair share of success to be an inspiration for others like them to achieve empowerment.

In Americanah, non-American Black women are depicted as immigrants who move to America to pursue their dreams. They aspire to get a better education, to have a better career, and to live well. However, behind these American Dreams are challenges that need to be tackled with making a lot of efforts, taking a lot of risks, and dealing with various consequences. Struggling to achieve empowerment, they also have to confront discrimination, prejudice, and oppression from their society as non-American Black women.

At the end, the impacts of women's empowerment have a role in redefining gender equality in education, employment, and social changes. Family and other support circles are the ones who usually encourage women to redefine gender equality in achieving those three aspects. Empowerment and equality reflect the ideas of fourth-wave feminism that is still very much concerned with gender, class, race, and sexuality. The empowerment impacts in gaining gender equality bring non-American Black women to present themselves in society and prove their capacity. After gaining formal education and a better job, the non-American Black women realize that they also have a chance to live peacefully. Social changes in the standard of living depict their struggles, consequences, process, and risks in gaining empowerment and equality in American society.

Finally, the analysis results show that every non-American Black woman is free to obtain a better life for her future. Discrimination, injustice, and racism have only made them motivated them to prove their existence and competence in society. The power to make themselves capable of doing things and achieving their dreams has changed their destiny. The empowerment enables them to feel free to determine their goals, in spite of where they come from and what their race is. Black people, especially Black women, have a concern about race, gender, and class when they live in America. However, the arrival of the new wave can help them reduce their uneasiness by using technology or online media to share their stories and concerns. In the fourth wave of feminism, technology becomes a new force that supports women to share their stories, concerns, and ideas online. Free to use, such technology makes it easy for activists to empower women around the globe.

\section{REFERENCES}

Adichie, C. N. (2013). Americanah. Anchor Books.

Apfelbaum, E. P., Sommers, S. R., \& Norton, M. I. (2008). Seeing race and seeming racist? Evaluating strategic colorblindness in social interaction. Journal of Personality and Social Psychology, 95(4), 918-932. https://doi.org/10.1037/a0011990

Asmarani, D. (2015, March 9). 10 ways you're wrong aboutfeminism. https://magdalene.co/story/10ways-youre-wrong-about-feminism

Belalcázar, C., Unesco, \& Education Sector. (2015). Mobile phones \& literacy: Empowerment in women's hands : a cross-case analysis of nine experiences. http://unesdoc.unesco.org/ images/0023/002343/234325E.pdf

Casimir, L. (2008, May 20). Data show Nigerians the most educated in the US: Bachelor's and beyond. https://www.chron.com/news/article/Datashow-Nigerians-the-most-educated-in-theU-S-1600808.php

Chamberlain, P. (2017a). The Feminist Fourth Wave. Springer International Publishing. https://doi. org/10.1007/978-3-319-53682-8

Chamberlain, P. (2017b). The Feminist Fourth Wave. Springer International Publishing. https://doi. org/10.1007/978-3-319-53682-8

Chiang, C.-W., Betanzos, E., \& Savage, S. (2019). The Challenges and Trends of Deploying Blockchain in the Real World for the Users' Need. Journal of Cyberspace Studies, 3(2). https://doi. org/10.22059/jcss.2019.72454

Collins, P. H. (2000). Black feminist thought: Knowledge, consciousness, and the politics of empowerment. Palgrave Macmillan.

Duflo, E. (2012). Women Empowerment and Economic Development. Journal of Economic Literature, 50(4), 1051-1079. https://doi.org/10.1257/ jel.50.4.1051

Hunt, A. (2013, August 2). Education and empowerment: You're nobody until somebody train you. https:// www.theguardian.com/global-developmentprofessionals-network/2013/aug/02/educationempowerment-adolescent-girls

Kabeer, N. (2005). Gender equality and women's empowerment: A critical analysis of the third millennium development goal 1. Gender \& Development, 13(1), 13-24. https://doi.org/10. 
$1080 / 13552070512331332273$

Radford-Hill, S. (2000). Further to fly: Black women and the politics of empowerment. University of Minnesota Press.

Rahman, A. (2013). Women's Empowerment: Concept and Beyond. 6.

Rivers, N. (2017). Postfeminism(s) and the Arrival of the Fourth Wave. Springer International Publishing. https://doi.org/10.1007/978-3-319-59812-3

Rowe, J. C. (Ed.). (2000). Post-nationalist American studies. Los Angeles: University of California Press.

Chiang, C.-W., Betanzos, E., \& Savage, S. (2019). The Challenges and Trends of Deploying Blockchain in the Real World for the Users' Need. Journal of Cyberspace Studies, 3(2). https://doi. org/10.22059/jcss.2019.72454

Spalter-Roth, R., \& Lowenthal, T. A. (2005, June). Race, ethnicity, and the American labor market: What's at work? ASA Series on How Race and Ethnicity Matter. (pp. 1-14). https://www.asanet.org/ research-and-publications/research-sociology/ research-briefs/race-ethnicity-and-americanlabor-market-whats-work

TED. (2016, March 28). Teach girls bravery, not perfection: Reshma Saujani [Video file]. YouTube. https:// www.youtube.com/watch? $\mathrm{v}=\mathrm{fC} 9$ da6eqaqg
Tijani, M. (2016, November 15). 10,674 Nigerians studying in the US - highest in 30 years. https:// www.thecable.ng/10674-nigerians-studying-ushighest-30-years

United Nation Women. (2020, March 9-20). Review and appraisal of the implementation of the Beijing Declaration and Platform for Action and the outcomes of the twenty-third special session of the General Assembly. https://undocs.org/E/ CN.6/2020/3

Labor Force Characteristics by Race and Ethnicity, 2009. (2010, August). 56. https://www.bls.gov/ opub/reports/race-and-ethnicity/archive/race_ ethnicity_2009.pdf

Vertovec, S. (2009). Transnationalism. Routledge.

Wootson Jr., C. R., Williams, V., Balz, D., \& Clement, S. (2020, January 17). Black Americans are deeply pessimistic about the country under Trump, whom more than 8 to 10 describe as 'a racist,' Post-Ipsos poll finds. https://www.washingtonpost.com/ politics/black-americans-deeply-pessimisticabout-country-under-president-who-morethan-8-in-10-describe-as-a-racist-post-ipsospoll-finds/2020/01/16/134b705c-37de-11eabb7b-265f4554af6d_story.html 